\title{
Phosphorus Addition Increases Aboveground Biomass but Does Not Change N:P Stoichiometry of Chinese fir (Cunninghamia lanceolata) Seedlings under Nitrogen Deposition
}

\author{
Qiang Yang', Quan Li ${ }^{1 \#, ~ J u n b o ~ Z h a n g 1, ~ W e n f a ~ X i a o ², ~ X i n z h a n g ~ S o n g 1 * ~}$ \\ ${ }^{1}$ State Key Laboratory of Subtropical Silviculture, Zhejiang A\&F University, Hangzhou 311300, China \\ ${ }^{2}$ Research Institute of Forest Ecology, Environment and Protection, Chinese Academy of Forestry, \\ Beijing 100091, China
}

Received: 29 February 2020

Accepted: 20 June 2020

\begin{abstract}
Nitrogen deposition usually increases plant N:P stoichiometry and potentially intensifies phosphorus limitations for plant aboveground or belowground growth. However, the effects of $\mathrm{P}$ addition on N:P stoichiometry, aboveground biomass (AGB), and belowground biomass (BGB) of the subtropical Chinese fir (Cunninghamia lanceolata) with $\mathrm{N}$ deposition remains poorly understood. A 1-year study was conducted to examine the effects of $\mathrm{N}$ deposition $\left(0,30\right.$, and $60 \mathrm{~kg} \mathrm{~N} \mathrm{ha}^{-1} \mathrm{yr}^{-1}$; N0, N30, and N60) and $\mathrm{P}$ application $\left(0,20\right.$, and $40 \mathrm{mg} \mathrm{kg}^{-1} ; \mathrm{P} 0, \mathrm{P} 20$, and $\left.\mathrm{P} 40\right)$ on biomass production and $\mathrm{N}: \mathrm{P}$ stoichiometry in Chinese fir seedlings. N60 alone significantly increased the total biomass; AGB; BGB; $\mathrm{N}$ concentrations in the leaves, branches, and roots; and root $\mathrm{N}: \mathrm{P}$ ratio. $\mathrm{P}$ addition alone significantly increased total biomass and AGB. P40 significantly increased P concentration in the leaves, branches, stems, and roots but did not influence $\mathrm{N}$ concentration and decreased the N:P ratio. Compared to that with N60 alone, P40 combined with N60 significantly increased the AGB, N concentration in the branches and roots, and N:P ratio of the leaves but significantly decreased the BGB and root-shoot ratio ratio. Total biomass and $\mathrm{AGB}$ were significantly and positively correlated with leaf $\mathrm{N}$ and $\mathrm{P}$ concentrations. Leaf $\mathrm{N}$ concentration was significantly and positively correlated with soil available $\mathrm{N}$ concentration. Leaf $\mathrm{P}$ concentration exhibited a significant and positive correlation with soil available $\mathrm{P}$. These findings provide new ideas about the effect of $\mathrm{P}$ addition on Chinese fir biomass accumulation and N:P stoichiometry under $\mathrm{N}$ deposition.
\end{abstract}

Keywords: aboveground biomass, belowground biomass, $\mathrm{N}$ addition, $\mathrm{P}$ application, N:P ratio

\# These authors contributed equally to this work and should be considered as co-first authors

*e-mail: songxinzhang@gmail.com 


\section{Introduction}

Nitrogen $(\mathrm{N})$ and phosphorus $(\mathrm{P})$ important roles in plant growth [1] and productive forces in terrestrial ecosystems [2]. According to ecological chemometrics, changes in the plant $\mathrm{N}: \mathrm{P}$ ratio affect the ratio of RNA to protein, which affects the growth rate of plants [3]. Furthermore, several studies have shown that a low N:P ratio is related to a high rate of increase [3-5]. Reactive $\mathrm{N}$ enters an ecosystem through multiple routes, for example, atmospheric $\mathrm{N}$ deposition, $\mathrm{N}$ fixation by beans, and agricultural fertilization. $\mathrm{P}$ produced by rock weathering is the main source of available $\mathrm{P}$ for plants [6]. The disequilibrium in $\mathrm{N}$ or $\mathrm{P}$ inputs into the ecosystem can have a significant influence on plant $\mathrm{N}: \mathrm{P}$ ratios, which consequently affect plant biomass production $[6,7]$. However, research into the influence of $\mathrm{N}-\mathrm{P}$ imbalances on the plant $\mathrm{N}: \mathrm{P}$ ratio, aboveground biomass (AGB), and belowground biomass (BGB) is still lacking, particularly in the case of anthropogenic $\mathrm{N}$ input $[8,9]$.

Anthropogenic activities, such as fossil fuel combustion, fertilizer use, and intensive animal husbandry, have produced large amounts of $\mathrm{N}$-containing compounds, which increases atmospheric $\mathrm{N}$ deposition [10]. Huge $\mathrm{N}$ input alters nutrient cycling in terrestrial ecosystems [11-13], for example, by accelerating $\mathrm{N}$ cycling $[8,14,15]$. Several studies have shown that $\mathrm{N}$ addition can increase leaf $\mathrm{N}$ concentration and $\mathrm{N}: \mathrm{P}$ ratios in boreal [15], temperate [5, 16, 17], and subtropical forest ecosystems [18, 19]. Plant biomass increases in temperate forests but does not significantly change in tropical forests with $\mathrm{N}$ addition [20]. A meta-analysis showed that $\mathrm{N}$ addition boosts the $\mathrm{N}: \mathrm{P}$ ratio of plants, $\mathrm{AGB}$, and $\mathrm{BGB}$ on a global scale [8]. However, these studies only focused on the biomass or foliar $\mathrm{N}: \mathrm{P}$ ratio $[9,21]$, and fewer studies have simultaneously probed the effect of $\mathrm{N}$ addition on the tissue $\mathrm{N}: \mathrm{P}$ ratio, $\mathrm{AGB}$, and $\mathrm{BGB}$ in forest ecosystems, especially in the context of plantations. In addition, as $\mathrm{N}$ increases, the increased $\mathrm{P}$ availability caused by $\mathrm{N}$ is insufficient to meet the increased $\mathrm{P}$ requirement [8], and thus, $\mathrm{P}$ limitation becomes the main factor limiting plant growth [7]. Some studies have shown that an increase in the proportion of $\mathrm{N}: \mathrm{P}$ in tissues usually indicates that $\mathrm{P}$ limits plant growth [9, 21]. Therefore, $\mathrm{P}$ application could decrease the adverse effect of the $\mathrm{P}$ limit on plant biomass accumulation that is caused by increased $\mathrm{N}$ deposition. $\mathrm{P}$ application increases $\mathrm{AGB}$ and the plant $\mathrm{N}: \mathrm{P}$ ratio under improved $\mathrm{N}$ conditions in a terrestrial ecosystem [8]. Huang et al. [22] observed that $\mathrm{P}$ application increases the BGB and $\mathrm{P}$ concentration of licorice (Glycyrrhiza uralensis) and Pennisetum (Pennisetum alopecuroides), resulting in a decreased tissue N:P ratio. However, there is a lack of research into whether $\mathrm{P}$ addition mitigates $\mathrm{N}$-induced $\mathrm{P}$ limitations for tissue N:P ratios, $\mathrm{AGB}$, and $\mathrm{BGB}$ in subtropical forests.
The Chinese fir (Cunninghamia lanceolata) is a common tree species in China and is widely distributed in southern China $[23,24]$ with a huge economic value owing to its characteristic rapid growth and the highquality material it provides [25]. In subtropical China, the mean annual bulk deposition of $\mathrm{N}$ has reached 30 $\mathrm{kg} \mathrm{N} \mathrm{ha}{ }^{-1} \mathrm{yr}^{-1}$ [26] and is expected to increase in the next few decades [27, 28]. Furthermore, $\mathrm{P}$ is a limiting factor for plant growth in southern China [29-31]. To investigate the effect of $\mathrm{P}$ addition on tissue $\mathrm{N}: \mathrm{P}$ ratios, $\mathrm{AGB}$, and $\mathrm{BGB}$ of the Chinese fir with $\mathrm{N}$ deposition, we applied additional $\mathrm{N}$ and $\mathrm{P}$ to Chinese fir seedlings in southeastern China. We hypothesized that (1) $\mathrm{N}$ addition would improve the tissue $\mathrm{N}: \mathrm{P}$ ratios, AGB, and $\mathrm{BGB}$, (2) $\mathrm{P}$ addition would improve the tissue $\mathrm{N}: \mathrm{P}$ ratios, $\mathrm{AGB}$, and $\mathrm{BGB}$, (3) $\mathrm{P}$ addition could decrease the $\mathrm{N}$-induced $\mathrm{N}: \mathrm{P}$ ratio and increase plant biomass accumulation.

\section{Materials and Methods}

\section{Experimental Site}

The study location was situated in Lin'an District, Hangzhou City, Zhejiang Province, China $\left(30^{\circ} 14^{\prime} \mathrm{N}\right.$, $\left.119^{\circ} 42^{\prime} \mathrm{E}\right)$. The site has a subtropical monsoon climate. The mean annual precipitation is $1420 \mathrm{~mm}$, and the mean annual air temperature is $15.6^{\circ} \mathrm{C}$. The local soil type belongs to the yellow-red soil category (Chinese soil classification system) [32].

\section{Experimental Design}

A pot experiment was set up with nine treatments in December 2016. Every treatment had three replicates. The 27 plots $(1 \times 1 \mathrm{~m})$ were separated through $1 \mathrm{~m}$ buffer zones. Five 3-year-old Chinese fir seedlings were evenly distributed in each plot. Soil and Chinese fir seedlings of the pot experiment were sampled from the study site. The nine treatments were as follows: control (without $\mathrm{N}, \mathrm{P}$ addition), low $\mathrm{N}$ deposition (N30: $30 \mathrm{~kg} N \mathrm{ha}^{-1} \mathrm{yr}^{-1}$ ), high $\mathrm{N}$ deposition (N60: $60 \mathrm{~kg} \mathrm{~N} \mathrm{ha} \mathrm{yr}^{-1}$ ), low $\mathrm{P}$ addition (P20: $20 \mathrm{mg} \mathrm{kg}^{-1}$ ), high $\mathrm{P}$ addition (P40: $40 \mathrm{mg} \mathrm{kg}^{-1}$ ), and combinations of low or high $\mathrm{N}$ deposition and $\mathrm{P}$ addition (N30-P20, N30-P40, N60-P20, and N60-P40). The $\mathrm{N}$ deposition levels were based on this locality level of $\mathrm{N}$ deposition (30 $\mathrm{kg} \mathrm{N} \mathrm{ha}^{-1} \mathrm{yr}^{-1}$ ) [26] and a method widely used by former research imitating $\mathrm{N}$ deposition [18]. Based on a report stating that wet $\mathrm{N}$ deposition in China consists of $\mathrm{NH}_{4}^{+}(56.1 \%)$ and $\mathrm{NO}_{3}^{-}$ (43.9\%) [33] and a $\mathrm{NH}_{4}^{+}: \mathrm{NO}_{3}^{-}$ratio of approximately 1.28 [34], we chose ammonium nitrate $\left(\mathrm{NH}_{4} \mathrm{NO}_{3}\right)$ as the $\mathrm{N}$ origin. From January to December 2017, an $\mathrm{NH}_{4} \mathrm{NO}_{3}$ solution (6 L) was evenly sprayed in each plot over the canopy of the Chinese fir seedlings using an electric sprayer every 2 weeks. The same amount of $\mathrm{N}$-free 
water was added to the control treatment. In January 2017, soil available P concentration was adjusted once by adding $\mathrm{KH}_{2} \mathrm{PO}_{4}$ to make it coincide with these experimental criteria. Meanwhile, Hoagland nutrient solution at a concentration of $1 \%$ (e.g. $60 \mathrm{~mL}$ nutrient solution dissolved in $6 \mathrm{~L}$ of water) was replenished for all seedlings to guarantee the necessary levels of other nutrients.

\section{Soil and Plant Sampling and Analyses}

In January 2018, all seedlings and their rhizosphere soil were collected and transferred to the laboratory. Plant tissues (root, stem, branch, and leaf) were cleaned with distilled water and dried in a $65^{\circ} \mathrm{C}$ oven for $48 \mathrm{~h}$. Then, they were weighed to determine biomass; AGB included the sum of the biomass of leaves, branches, and stems, whereas BGB refers to the biomass of roots. The dried plant samples were homogenized with a grinder and passed through a $0.15 \mathrm{~mm}$ sieve for subsequent experiments. Plant $\mathrm{N}$ was isolated with $\mathrm{H}_{2} \mathrm{SO}_{4}-\mathrm{H}_{2} \mathrm{O}_{2}$ and the $\mathrm{N}$ concentration was determined by the semi-micro-Kelvin method [18]. Plant $\mathrm{P}$ was isolated with $\mathrm{H}_{2} \mathrm{SO}_{4}-\mathrm{H}_{2} \mathrm{O}_{2}$ and its concentration was determined by the molybdenum antimony colorimetric method [35].

The soil samples were transported to the laboratory in a constant temperature box containing ice then air-dried and stored at room temperature $\left(25^{\circ} \mathrm{C}\right)$. Visible stones, roots, and litter were removed then through a $0.15 \mathrm{~mm}$ sieve for soil physicochemical property analysis. We used an elemental analyzer (Elementar Vario EL III, Germany) to determine the concentration of total $\mathrm{N}(\mathrm{TN})$ and total P (TP) in soil. The molybdenum blue method was used to determine soil available P (AP) [36]. Soil available N (AN) was measured by the hot alkaline permanganate method [37].

\section{Statistical Analyses}

The statistical significance of discrepancies in the total biomass, $\mathrm{AGB}, \mathrm{BGB}$, root-shoot ratio ratio, $\mathrm{N}$ and $\mathrm{P}$ concentration, and $\mathrm{N}: \mathrm{P}$ ratios of plants among all treatments were tested by one-way analysis of variance (ANOVA), and the least significant difference test was passed. The influence of $\mathrm{N}$ deposition and $\mathrm{P}$ addition on the biomass (total biomass, AGB, BGB), root-shoot ratio ratio, and ecological stoichiometry were inspected by two-way ANOVA. The relevance of biomass (total biomass, AGB, BGB), plant ecological stoichiometry ( $\mathrm{N}$ and $\mathrm{P}$ concentration), root-shoot ratio ratio, and soil properties (soil AN, AP, TN, and TP concentration) was investigated using Pearson correlation analysis. We used SPSS 18.0 for Windows (SPSS Inc., Chicago, Illinois) for data analysis.

\section{Results and Discussion}

\section{Effect of N Addition on Biomass Production and N:P Stoichiometry}

Compared to those in the control, N60 treatment significantly increased total biomass $(18.03 \%$, Fig. 1a), AGB (27.03\%, Fig. 1b), BGB (6.97\%, Fig. 1c), and leaf $\mathrm{N}$ concentration (16.26\%, Fig. 2a). Our results indicated that high $\mathrm{N}$ addition $\left(\geq 60 \mathrm{~kg} \mathrm{ha}^{-1} \mathrm{yr}^{-1}\right)$ significantly increased the total biomass, $\mathrm{AGB}, \mathrm{BGB}$, and leaf and branch $\mathrm{N}$ concentration. These findings partly supported our first hypothesis that $\mathrm{N}$ deposition can enhance the AGB and BGB of Chinese fir seedlings. Some studies put forward that $\mathrm{N}$ addition increases the AGB of Arctic tundra vegetation [38], biomass production of spruce (Picea asperata) [39], and growth of Cryptocarya chinensis (Cryptocarya concinna) seedlings [40]. Numerous studies have shown that plant biomass is significantly related to photosynthesis [41-43]. Leaf $\mathrm{N}$ is related to photosynthetic processes and plays a basic function in leaf photosynthesis [44]. The positive response of photosynthesis to leaf $\mathrm{N}$ concentration has been well confirmed in many species [45]. In our research, the $\mathrm{N}$ concentration in leaves was found to increase significantly with $\mathrm{N}$ addition, which in turn led to increased plant photosynthetic rate and biomass production (Fig. 3a). Our study also found that leaf $\mathrm{N}$ concentration was significantly and positively correlated with total biomass and AGB $(P<0.05$, Table 2), which indirectly supports the aforementioned point that high leaf $\mathrm{N}$ concentrations can promote plant biomass production. Some studies also found that $\mathrm{N}$ addition significantly improves leaf $\mathrm{N}$ concentration in Chinese fir [18] and red pine (Pinus densiflora) seedlings [46]. This might be because plants could then take up more $\mathrm{N}$, which is attributed to $\mathrm{N}$ addition increasing soil AN concentration. Our study found that soil AN concentration significantly increased following $\mathrm{N}$ addition (Fig. S1c) and had a significant positive correlation with leaf $\mathrm{N}$ concentration $(P<0.05$, Table 3), which supports the previously mentioned point that $\mathrm{N}$ addition can improve plant $\mathrm{N}$ concentrations. In addition, our previous study found that $\mathrm{N}$ addition significantly improves the maximum net photosynthetic rate and SPAD value of Chinese fir trees [47], which might provide further evidence that $\mathrm{N}$ addition promotes plant biomass production.

Plant biomass allocation between above- and belowground organs provides an important reference value to connect aboveground productivity and belowground $\mathrm{C}$ sequestration [48]. The supply situation of aboveground resources (light and $\mathrm{CO}_{2}$ ) and belowground resources (water and nutrients) affect biomass allocation [49], proving. that plants have high adaptability to environmental changes $[50,51]$. In a nutrient-deficient environment, adding fertilizers can 
Table. 1 Two-way ANOVA on the effects of $\mathrm{N}$ deposition and P addition on biomass and N:P stoichiometry of Chinese fir seedlings.

\begin{tabular}{|c|c|c|c|c|c|c|c|c|c|}
\hline \multirow{2}{*}{ Difference source } & \multicolumn{3}{|c|}{$\mathrm{N}$ addition } & \multicolumn{3}{|c|}{$P$ addition } & \multicolumn{3}{|c|}{ Interaction } \\
\hline & $d f$ & $\mathrm{~F}$ & $P$ & $d f$ & $\mathrm{~F}$ & $P$ & $d f$ & $\mathrm{~F}$ & $P$ \\
\hline AGB & 2 & 4.977 & 0.0451 & 2 & 9.5474 & 0.0297 & 4 & 9.638 & 0.0289 \\
\hline BGB & 2 & 15.205 & 0.0198 & 2 & 2.7652 & 0.1534 & 4 & 4.968 & 0.0452 \\
\hline Total biomass & 2 & 10.892 & 0.0287 & 2 & 9.3488 & 0.0307 & 4 & 5.351 & 0.0431 \\
\hline Root-shoot ratio & 2 & 11.988 & 0.0241 & 2 & 9.7341 & 0.0287 & 4 & 0.158 & 0.151 \\
\hline Leaf $\mathrm{N}$ concentration & 2 & 8.466 & 0.0387 & 2 & 2.034 & 0.1487 & 4 & 6.513 & 0.0411 \\
\hline Branch $\mathrm{N}$ concentration & 2 & 6.732 & 0.0409 & 2 & 1.147 & 0.5551 & 4 & 4.68 & 0.0471 \\
\hline 1Stem $\mathrm{N}$ concentration & 2 & 4.757 & 0.0457 & 2 & 0.977 & 0.8162 & 4 & 5.084 & 0.0441 \\
\hline Root $\mathrm{N}$ concentration & 2 & 5.668 & 0.0421 & 2 & 1.947 & 0.5649 & 4 & 7.225 & 0.0401 \\
\hline Leaf $P$ concentration & 2 & 2.302 & 0.1621 & 2 & 11.5237 & 0.0248 & 4 & 2.5321 & 0.1544 \\
\hline Branch $\mathrm{P}$ concentration & 2 & 4.162 & 0.0841 & 2 & 13.1487 & 0.0199 & 4 & 8.5974 & 0.0364 \\
\hline Stem $P$ concentration & 2 & 3.954 & 0.2214 & 2 & 8.0914 & 0.0394 & 4 & 1.3347 & 0.2416 \\
\hline Root $\mathrm{P}$ concentration & 2 & 0.579 & 0.4589 & 2 & 16.0887 & 0.0161 & 4 & 6.9487 & 0.0399 \\
\hline Leaf N:P ratio & 2 & 1.5478 & 0.2248 & 2 & 9.9321 & 0.0294 & 4 & 7.9146 & 0.0304 \\
\hline Branch N:P ratio & 2 & 6.1234 & 0.0411 & 2 & 9.1543 & 0.0324 & 4 & 3.9562 & 0.1538 \\
\hline Stem N:P ratio & 2 & 5.9877 & 0.0419 & 2 & 3.9468 & 0.0879 & 4 & 9.5246 & $\mathbf{0 . 0 3 0 7}$ \\
\hline Root N:P ratio & 2 & 8.6317 & 0.0369 & 2 & 15.3476 & 0.0187 & 4 & 8.9166 & 0.035 \\
\hline
\end{tabular}

AGB: aboveground biomass; BGB: belowground biomass.
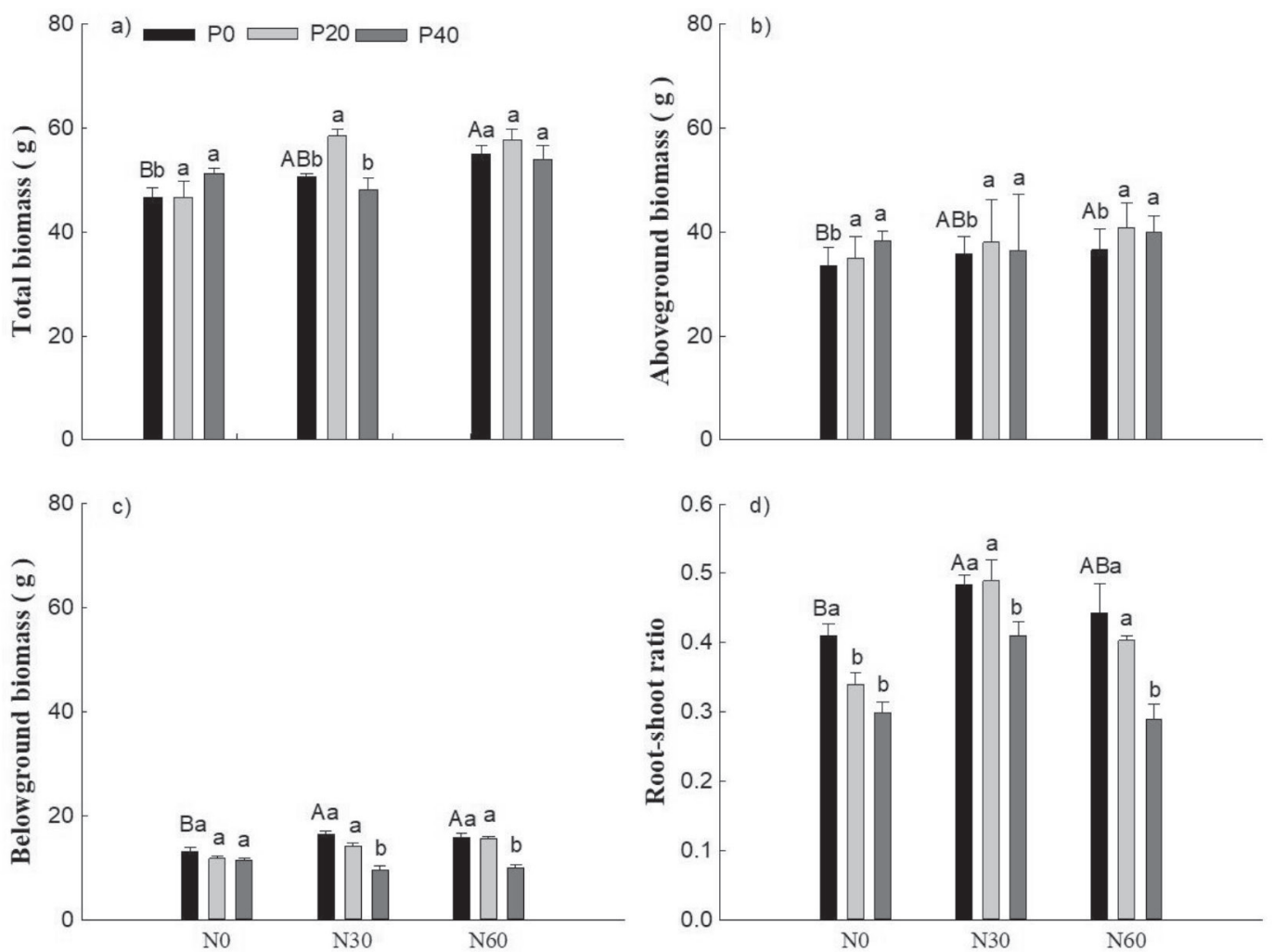

Fig. 1. Effects of $\mathrm{N}$ deposition ( $\left.\mathrm{N} 0,0 \mathrm{~kg} \mathrm{~N} \mathrm{ha}{ }^{-1} \mathrm{yr}^{-1} ; \mathrm{N} 30,30 \mathrm{~kg} \mathrm{~N} \mathrm{ha}^{-1} \mathrm{yr}^{-1} ; \mathrm{N} 60,60 \mathrm{~kg} \mathrm{~N} \mathrm{ha}^{-1} \mathrm{yr}^{-1}\right)$ and $\mathrm{P}$ addition $(\mathrm{P} 0,0 \mathrm{mg} \mathrm{kg}$; $\mathrm{P} 20$, $20 \mathrm{mg} \mathrm{kg}^{-1} ; \mathrm{P} 40,40 \mathrm{mg} \mathrm{kg}^{-1}$ ) on total biomass a), aboveground biomass b), belowground biomass c), and root-shoot ratio d) of Chinese fir seedlings. Different capital letters indicate significant differences among $\mathrm{N}$ addition alone $(P<0.05)$. Different lowercase letters indicate significant differences among $\mathrm{P}$ addition at the identical $\mathrm{N}$ addition $(P<0.05)$. 
Table 2. Pearson correlation coefficients between plant total biomass, AGB, and BGB, and root-shoot ratio and plant N:P stoichiometry.

\begin{tabular}{|c|c|c|c|c|}
\hline & Total biomass & AGB & BGB & Root-shoot ratio \\
\hline Leaf N concentration & $0.318^{*}$ & $0.386^{*}$ & -0.197 & $-0.481^{*}$ \\
\hline Branch N concentration & 0.225 & $0.337^{*}$ & -0.088 & -0.142 \\
\hline Stem N concentration & -0.160 & 0.033 & -0.126 & -0.114 \\
\hline Root N concentration & $0.420^{*}$ & $0.492^{*}$ & -0.215 & $-0.387^{*}$ \\
\hline Leaf P concentration & $0.365^{*}$ & $0.248^{*}$ & 0.164 & $-0.297^{*}$ \\
\hline Branch P concentration & 0.166 & 0.204 & -0.161 & -0.206 \\
\hline Stem P concentration & 0.112 & 0.183 & 0.214 & 0.118 \\
\hline Root P concentration & $0.631^{* *}$ & $0.721^{* *}$ & $0.395^{*}$ & $-0.481^{*}$ \\
\hline Leaf N:P ratio & $0.296^{*}$ & $0.490^{*}$ & -0.187 & $-0.375^{*}$ \\
\hline Branch N:P ratio & 0.089 & 0.246 & -0.212 & -0.222 \\
\hline Stem N:P ratio & -0.010 & 0.183 & -0.037 & -0.178 \\
\hline Root N:P ratio & $0.273^{*}$ & $0.314^{*}$ & -0.060 & $-0.354^{*}$ \\
\hline
\end{tabular}

AGB: aboveground biomass; BGB: belowground biomass.

$* P<0.05, * * P<0.01$

significantly increase the concentration of corresponding nutrients in the soil and the growth limitation of plants due to a lack of nutrients can be eased [52]. In our research, N30 treatment significantly increased the rootshoot ratio ratio and BGB. One possibility is that $\mathrm{N}$ addition intensifies $\mathrm{P}$ limitations for plant growth $[5,16$,
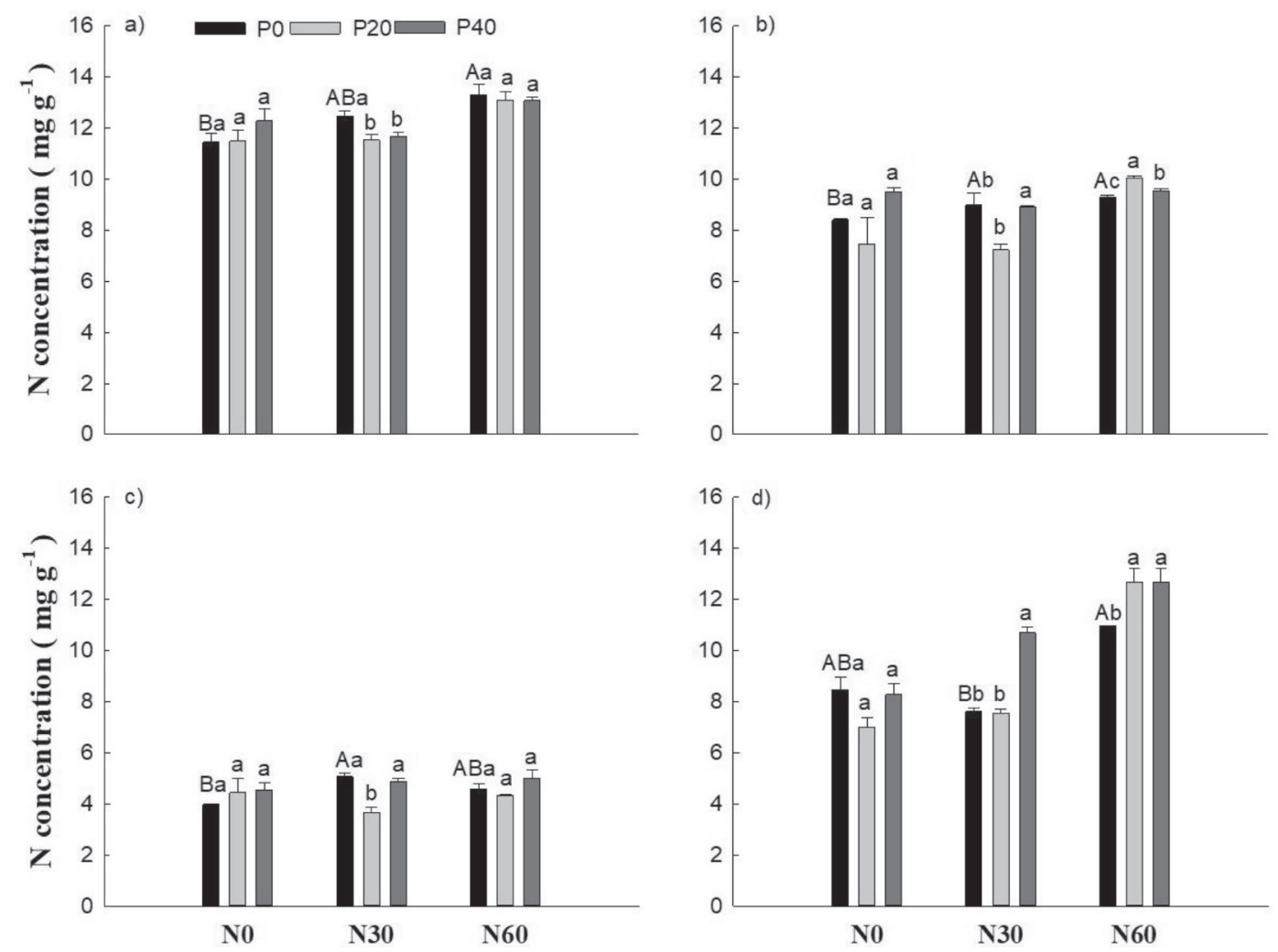

Fig. 2. Effects of $\mathrm{N}$ deposition (N0, $\left.0 \mathrm{~kg} \mathrm{~N} \mathrm{ha}^{-1} \mathrm{yr}^{-1} ; \mathrm{N} 30,30 \mathrm{~kg} \mathrm{~N} \mathrm{ha}^{-1} \mathrm{yr}^{-1} ; \mathrm{N} 60,60 \mathrm{~kg} \mathrm{~N} \mathrm{ha}^{-1} \mathrm{yr}^{-1}\right)$ and $\mathrm{P}$ addition $\left(\mathrm{P} 0,0 \mathrm{mg} \mathrm{kg}{ }^{-1} ; \mathrm{P} 20\right.$, $20 \mathrm{mg} \mathrm{kg}^{-1} ; \mathrm{P} 40,40 \mathrm{mg} \mathrm{kg}^{-1}$ ) on $\mathrm{N}$ concentration of leaves a), branches b), stems c), and roots d) in Chinese fir seedlings. Different capital letters indicate significant differences among $\mathrm{N}$ addition alone $(P<0.05)$. Different lowercase letters indicate significant differences among $\mathrm{P}$ addition at the identical $\mathrm{N}$ addition $(P<0.05)$. 
53]. In conditions of $\mathrm{P}$ limitation, plants allocate more biomass to belowground organs (roots) to take up more $\mathrm{P}$ and thus produce more dry matter.

Compared to those in the control, the N30 treatment significantly increased branch $\mathrm{N}$ concentrations $(8.23 \%$, Fig. 2b), stem $\mathrm{N}$ concentrations (18.46\%, Fig. 2c), and the $\mathrm{N}: \mathrm{P}$ ratio (Fig. 4c); the N60 treatment also significantly increased $\mathrm{N}$ concentrations in the leaf and branch $(10.97 \%$, Fig. $2 b)$ and the root $\mathrm{N}: \mathrm{P}$ ratio (Fig. 4d). In the present study, $\mathrm{N}$ addition increased the $\mathrm{N}$ concentration in leaves, branches, stems, and roots but failed to stimulate $\mathrm{P}$ uptake in Chinese fir seedlings, resulting in an increased $\mathrm{N}: \mathrm{P}$ ratio, particularly in the roots, which further supports the contention that $\mathrm{N}$ addition intensifies $\mathrm{P}$ limitations. According to a generalization proposed by Tessier and Raynal [54], the plant growth rate can be reflected by the N:P ratio and $\mathrm{P}$ limitation often arises when the leaf $\mathrm{N}: \mathrm{P}$ ratio surpasses 16. Although plant roots are considered less sensitive to environmental changes than leaves, some studies have demonstrated that belowground stoichiometry is also sensitive to environmental changes [22]. In our research, $\mathrm{N}$ treatment significantly improved the root $\mathrm{N}: \mathrm{P}$ ratio to $>16$ (Fig. $4 \mathrm{~d}$ ), which might indicate $\mathrm{N}$ addition induced $\mathrm{P}$ limitation and provide further support for belowground stoichiometry being sensitive to $\mathrm{N}$ addition. These conclusions not only sustain our first hypothesis that $\mathrm{N}$ addition improves plant $\mathrm{N}: \mathrm{P}$ ratios but also agree with the results from research on forest ecosystems, which demonstrated that aggravating $\mathrm{N}$ deposition will exacerbate $\mathrm{P}$ limitations $[5,15,18]$.

\section{Effect of P Addition on Biomass Production and N:P Stoichiometry}

Compared to those in the control, the addition of $\mathrm{P}$ significantly increased total biomass (0.13-9.93\%, Fig. 1a) and AGB (4.31-14.69\%, Fig. 1b) but significantly decreased the root-shoot ratio ratio (Fig. 1d). Our results indicated that $\mathrm{P}$ application had a positive effect on total biomass and AGB but did not significantly affect BGB, which partly supports our second hypothesis that $\mathrm{P}$ addition will significantly increase AGB. Our observation is similar to the discovery of Mehta et al. [55], which showed that $\mathrm{P}$ addition significantly promotes biomass production in teak (Tectona grandis). $\mathrm{P}$ input can also promote the photosynthetic properties of wheat (Triticum aestivum) [56] and corn (Zea mays) [57]. This could be because $P$ plays a critical role in many plant activities, such as the formation of phospholipids, which are used in energy metabolism (e.g. NADPH and ATP) in light and dark reactions [44]. $\mathrm{P}$ is also one of the main constituent elements of chlorophyll, and chlorophyll content reflects plant photosynthetic levels [8]. Therefore, leaf $\mathrm{P}$ concentration is positively related to plant photosynthesis [32], and high photosynthetic levels can significantly promote biomass accumulation [58]. In the present study, $P$ addition significantly increase total biomass and $\mathrm{AGB}$, which is attributed to the increase in leaf $\mathrm{P}$ concentration. There was a significant and positive correlation between leaf $\mathrm{P}$ concentration and total biomass and AGB $(P<0.05$, Table 2), which indirectly supports our aforementioned point that $\mathrm{P}$ addition can promote biomass accumulation. In addition, our previous study found that $\mathrm{P}$ addition could improve the photosynthetic capacity in Chinese fir, which directly supports the notion that $\mathrm{P}$ addition could increase plant biomass [47].

P40 treatment significantly improved the $\mathrm{P}$ concentration in leaves $(51.51 \%$, Fig. 3a), branches (37.5\%, Fig. 3b), stems (35.42\%, Fig. 3c), and roots $(50 \%$, Fig. 3d) but significantly reduced the N:P ratio of leaves (Fig. 4a), branches (Fig. 4b), and roots (Fig. 4d) relative to those in the control. These results demonstrate that $\mathrm{P}$ application $(40 \mathrm{mg} \mathrm{kg}$ ) significantly increases plant tissue (leaves, branches, stems, and roots) $\mathrm{P}$ concentrations but decreases leaf, branch, and root $\mathrm{N}: \mathrm{P}$ ratios, which supports our first hypothesis that $\mathrm{P}$ addition can significantly increase plant $\mathrm{P}$ concentration but decrease the N:P ratio of Chinese fir seedlings. Huang et al. [22] reported that $\mathrm{P}$ addition significantly increases plant $\mathrm{P}$ concentrations but significantly decreases the root N:P ratio of licorice (Glycyrrhiza uralensis) and Pennisetum (Pennisetum alopecuroides). This might be explained by the fact that plants can take up more $\mathrm{P}$ in this context, leading to increased plant $\mathrm{P}$ concentrations. In our study, $\mathrm{P}$ addition significantly increased the soil AP concentration (Fig. S1d); moreover, there was a significant positive correlation between soil AP concentration and the $\mathrm{P}$ concentration of leaves and roots $(P<0.05$, Table 3$)$. These results indicate that $\mathrm{P}$ addition increases plant $\mathrm{P}$ concentrations and then decreases the N:P ratios. Liu et al. [59] found that $\mathrm{P}$ addition increases soil AP concentrations in eucalyptus seedlings. Previous studies reported that a leaf $\mathrm{N}: \mathrm{P}$ ratio 14 is indicative of plant growth that is limited by $\mathrm{N}$, whereas a leaf $\mathrm{N}: \mathrm{P}$ ratio $>16$ shows that $\mathrm{P}$ limits plant growth $[60,61]$. In our study, high $\mathrm{P}$ addition significantly decreased the leaf and root N:P ratio $(<14)$, indicating that $\mathrm{P}$ application exacerbates $\mathrm{N}$ limitation in Chinese fir seedlings.

\section{Interaction of $\mathrm{P}$ and $\mathrm{N}$ Addition on Biomass Production and N:P Stoichiometry}

Two-way ANOVA displayed that the N-P interaction significantly influenced total biomass, AGB, BGB, the $\mathrm{N}$ and $\mathrm{P}$ concentrations in leaves, branches, and roots $(P<0.05)$, and plant N:P ratios $(P<0.05)$ but did not significantly affect the root-shoot ratio ratio $(P>0.05$; Table 1). Compared to that with N30-P0 treatment, $P$ addition combined with N30 significantly increased AGB (3.18-6.25\%, Fig. 1b); further, the N30-P20 treatment significantly increased BGB (16.01\%, Fig. 1c) but significantly decreased $\mathrm{N}$ concentrations in leaves (7.54\%, Fig. 2a), branches (19.69\%, Fig. 2b), and stems $(27.42 \%$, Fig. $2 \mathrm{c})$, the $\mathrm{P}$ concentration in branches (22.22\%, Fig. 3b), and stem N:P ratios (Fig. 4c). The 
N30-P40 treatment significantly decreased BGB by $23.52 \%$ (Fig. 1c) and leaf $\mathrm{N}$ concentrations (6.34\%, Fig. 2a) but significantly increased root $\mathrm{N}$ concentrations $(40.42 \%$, Fig. 2d) and the N:P ratio $(P<0.05$;
Fig. 4d). Compared to those with N60-P0 treatment, P addition significantly increased $\mathrm{AGB}$ with $\mathrm{N}$ addition (18.3-20.65\%, Fig. 1b) and $\mathrm{N}$ concentrations in roots (19.32\%, Fig. 2d). Further, N60-P20 significantly
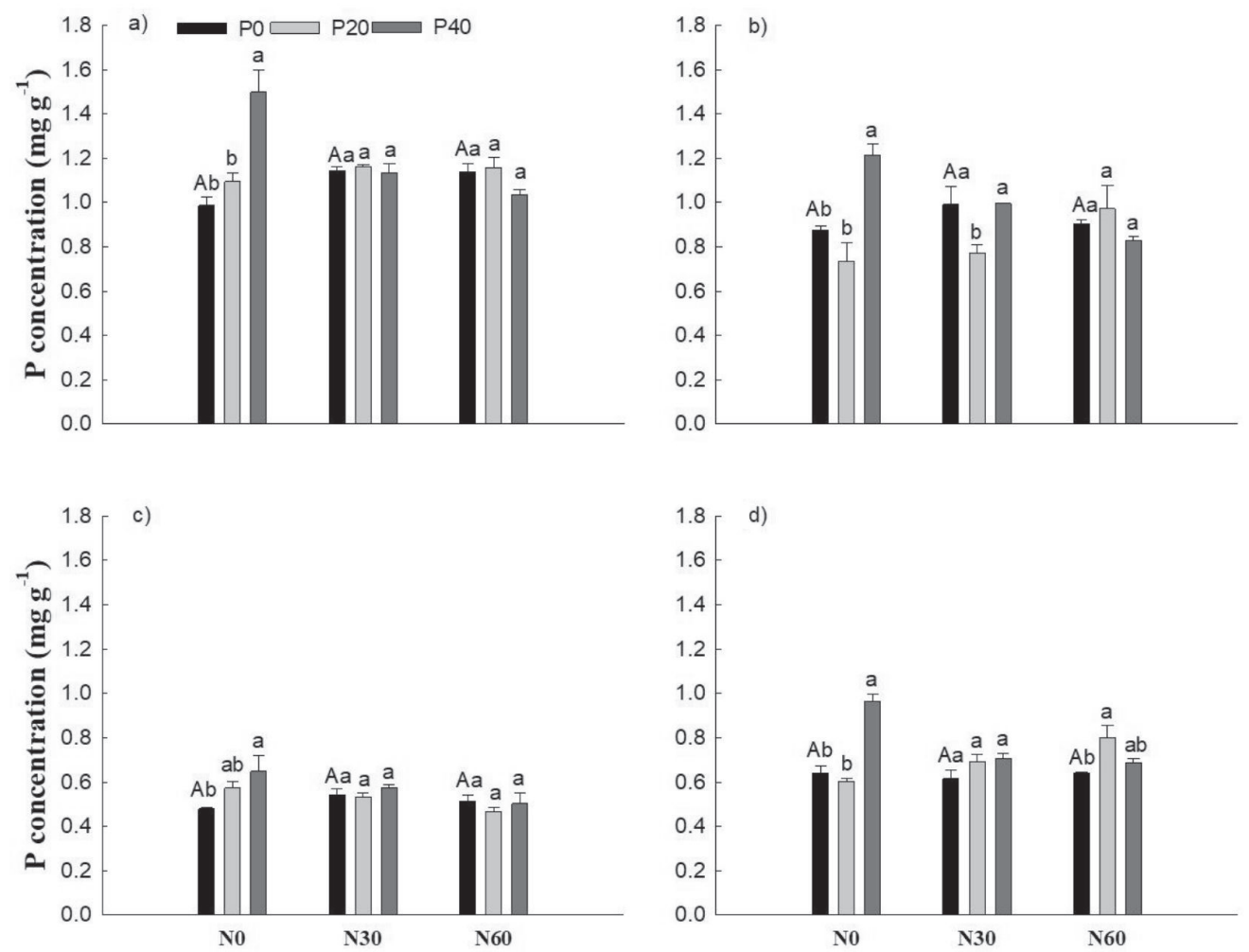

Fig. 3. Effects of $\mathrm{N}$ deposition (N0, $\left.0 \mathrm{~kg} \mathrm{~N}^{-1} \mathrm{yr}^{-1} ; \mathrm{N} 30,30 \mathrm{~kg} \mathrm{~N} \mathrm{ha}^{-1} \mathrm{yr}^{-1} ; \mathrm{N} 60,60 \mathrm{~kg} \mathrm{~N} \mathrm{ha}^{-1} \mathrm{yr}^{-1}\right)$ and $\mathrm{P}$ addition $(\mathrm{P} 0,0 \mathrm{mg} \mathrm{kg}$; $\mathrm{P} 20$, $20 \mathrm{mg} \mathrm{kg}^{-1} ; \mathrm{P} 40,40 \mathrm{mg} \mathrm{kg}^{-1}$ ) on P concentration of leaves a), branches b), stems c), and roots d) in Chinese fir seedlings. Different capital letters indicate significant differences among $\mathrm{N}$ addition alone $(P<0.05)$. Different lowercase letters indicate significant differences among $\mathrm{P}$ addition at the identical $\mathrm{N}$ addition $(P<0.05)$.

Table. 3 Pearson correlation coefficients between plant stoichiometry and soil properties.

\begin{tabular}{|c|c|c|c|c|c|}
\hline & TN & TP & AP & AN & AN:AP ratio \\
\hline Leaf N concentration & 0.238 & -0.306 & -0.035 & $0.503^{*}$ & $0.465^{*}$ \\
\hline Branch N concentration & 0.305 & -0.293 & -0.130 & 0.204 & 0.248 \\
\hline Stem N concentration & 0.093 & $-0.538^{*}$ & -0.100 & 0.224 & 0.137 \\
\hline Root N concentration & $0.338^{*}$ & -0.306 & -0.035 & $0.303^{*}$ & $0.465^{*}$ \\
\hline Leaf P concentration & 0.236 & 0.285 & $0.334^{*}$ & -0.182 & $-0.289^{*}$ \\
\hline Branch P concentration & 0.024 & -0.192 & 0.043 & -0.169 & 0.199 \\
\hline Stem P concentration & -0.214 & -0.146 & 0.145 & -0.066 & -0.275 \\
\hline Root P concentration & 0.255 & 0.451 & $0.424^{*}$ & -0.146 & -0.143 \\
\hline Leaf N:P ratio & -0.019 & $-0.582^{*}$ & -0.167 & $0.676^{* *}$ & $0.746^{* *}$ \\
\hline Branch N:P ratio & 0.451 & -0.101 & -0.146 & 0.013 & 0.005 \\
\hline Stem N:P ratio & 0.355 & -0.458 & -0.044 & 0.138 & 0.151 \\
\hline Root N:P ratio & 0.189 & -0.184 & $-0.282^{*}$ & $0.521 *$ & $0.539^{*}$ \\
\hline
\end{tabular}

TN: total N; TP: total P; AP: available P; AN: available N $* P<0.05, * * P<0.01$ 

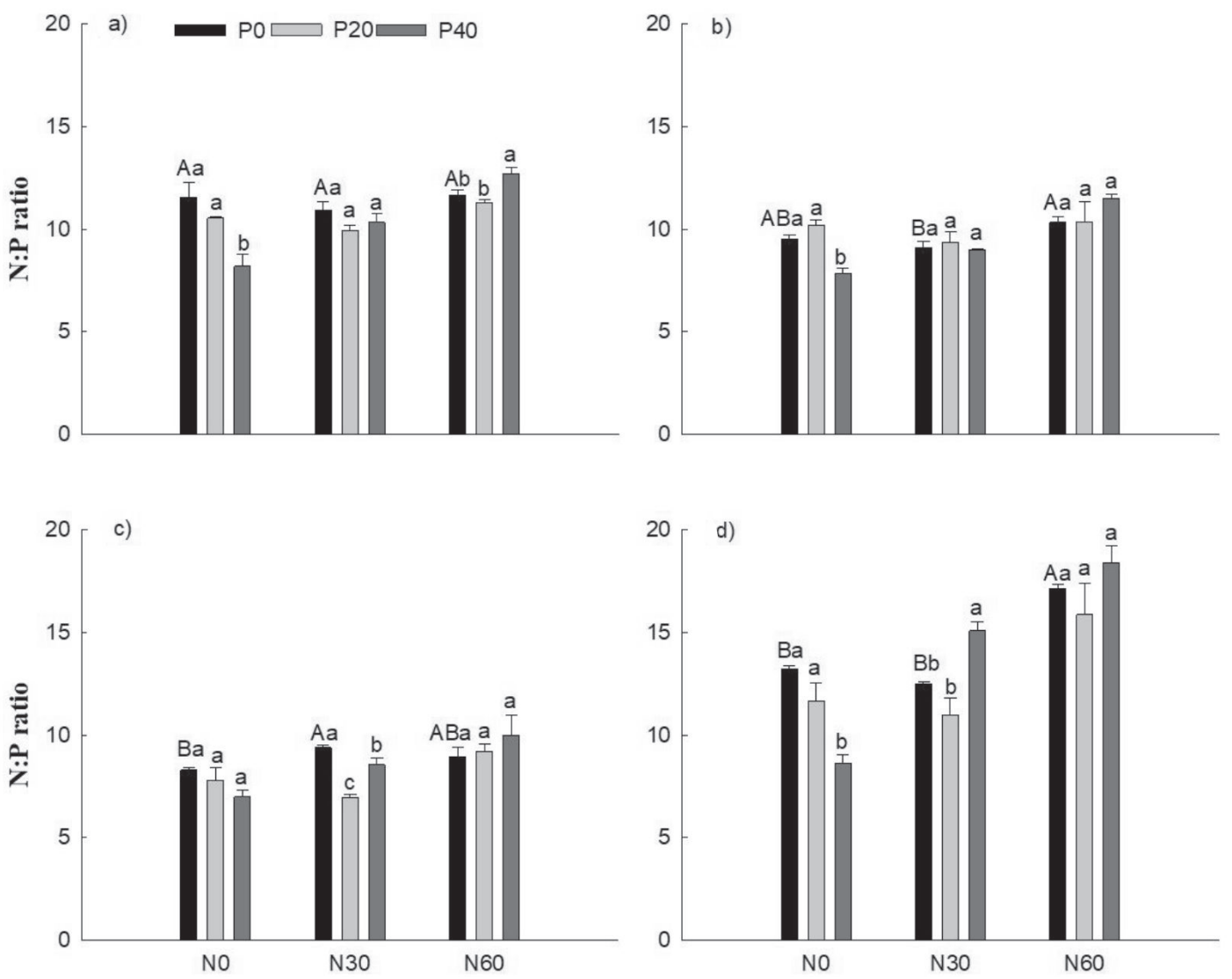

Fig. 4. Effects of $\mathrm{N}$ deposition ( $\left.\mathrm{N} 0,0 \mathrm{~kg} \mathrm{~N} \mathrm{ha}{ }^{-1} \mathrm{yr}^{-1} ; \mathrm{N} 30,30 \mathrm{~kg} \mathrm{~N}^{-1} \mathrm{yr}^{-1} ; \mathrm{N} 60,60 \mathrm{~kg} \mathrm{~N}^{-1} \mathrm{hr}^{-1}\right)$ and $\mathrm{P}$ addition $\left(\mathrm{P} 0,0 \mathrm{mg} \mathrm{kg}{ }^{-1} ; \mathrm{P} 20\right.$, $20 \mathrm{mg} \mathrm{kg}^{-1} ; \mathrm{P} 40,40 \mathrm{mg} \mathrm{kg}^{-1}$ ) on the N:P ratio of leaves a), branches b), stems c), and roots d) in Chinese fir seedlings. Different capital letters indicate significant differences among $\mathrm{N}$ addition alone $(P<0.05)$. Different lowercase letters indicate significant differences among $\mathrm{P}$ addition at the identical $\mathrm{N}$ addition $(P<0.05)$.

increased the root $\mathrm{P}$ concentration $(24.52 \%$, Fig. $3 \mathrm{~d})$ and N60-P40 significantly decreased BGB by $24.15 \%$ (Fig. 1c) but improved the leaf N:P ratio (Fig. 4a).

Our results indicated that the interaction between $\mathrm{N}$ and $\mathrm{P}$ addition only significantly enhanced AGB but did not significantly increase total biomass and $\mathrm{N}: \mathrm{P}$ ratios, which did not support the third hypothesis. A meta-analysis found that $\mathrm{P}$ addition increases AGB but decreases the root-shoot ratio ratio under increased $\mathrm{N}$ conditions [8]. $\mathrm{Wu}$ et al. [62] suggested that the N-P interaction significantly impacts the stem and leaf biomass of Fraxinus mandshurica seedlings. One possible explanation for this is that $\mathrm{N}$ and $\mathrm{P}$ addition provide nutrients that enrich plants, thereby overcoming the limitation of 'natural' nutrients, as light then becomes the main factor limiting the growth of plants. More photosynthetic production is therefore distributed to the aboveground part to accelerate growth, which is consistent with the findings of Guo et al. [63], which demonstrated that the interaction between $\mathrm{N}$ and $\mathrm{P}$ could increase the AGB of Potentilla fruticosa. In our research, the N-P interaction significantly promoted soil AN and AP concentrations (Fig. S1b, c), which further indicates that $\mathrm{N}$ and $\mathrm{P}$ addition provides nutrient enrichment for plants $(P<0.05$; Table 3$)$. Previous studies demonstrated that $\mathrm{P}$ addition increases plant
$\mathrm{P}$ concentrations and decreases the plant N:P ratio $[8$, 22]. Nevertheless, our study found that the interaction between $\mathrm{P}$ and $\mathrm{N}$ application did not significantly affect $\mathrm{P}$ concentrations and the $\mathrm{N}: \mathrm{P}$ ratio $(P<0.05$, Table 1), which indicates that $\mathrm{P}$ addition cannot alleviate $\mathrm{N}$-induced $\mathrm{P}$ limitations for Chinese fir seedling growth. This might be attributed to several factors, including $\mathrm{N}$ and $\mathrm{P}$ addition rates, tree types, soil types, and time; further research will be required to fully elucidate which of these factors is dominant.

\section{Conclusions}

$\mathrm{N}$ or $\mathrm{P}$ addition alone significantly increased the biomass production of Chinese fir seedlings. $\mathrm{N}$ addition mainly facilitated belowground growth and increased the root N:P ratios, whereas $\mathrm{P}$ addition mainly facilitated aboveground growth and increased $\mathrm{N}$ limitation. $\mathrm{P}$ addition significantly increased AGB but did not decrease the plant N:P ratio when combined with $\mathrm{N}$ deposition. This indicates that low $\mathrm{P}$ addition $\left(\leq 40 \mathrm{mg} \mathrm{kg}^{-1}\right)$ cannot effectively relieve the P limitation caused by $\mathrm{N}$ deposition in Chinese fir seedlings, which might require a large amount of $\mathrm{P}$ addition. There was a significantly positive correlation between the biomass of 
Chinese fir seedlings and foliar $\mathrm{N}$ and $\mathrm{P}$ concentrations. Soil AN and AP concentrations and the AN:AP ratio affected biomass production by influencing plant nutrition ( $\mathrm{N}$ and $\mathrm{P}$ ). As we only investigated Chinese fir seedlings, the long-term effects of $\mathrm{N}$ and $\mathrm{P}$ addition on Chinese fir tree biomass and N:P stoichiometry should be evaluated in future studies.

\section{Acknowledgments}

The study was funded by the National Key Research and Development Program of China (Grant
No. 2016YFD0600201), National Natural Science Foundation of China (Grant No. 31971623), and Province-Academy Cooperation Project of Zhejiang Province and the Chinese Academy of Forestry (Grant No. 2016SY06). We also thank Qiao Wang for her help in performing experiments.

\section{Conflict of Interest}

The authors declare no conflict of interest.

\section{Supplementary Material}
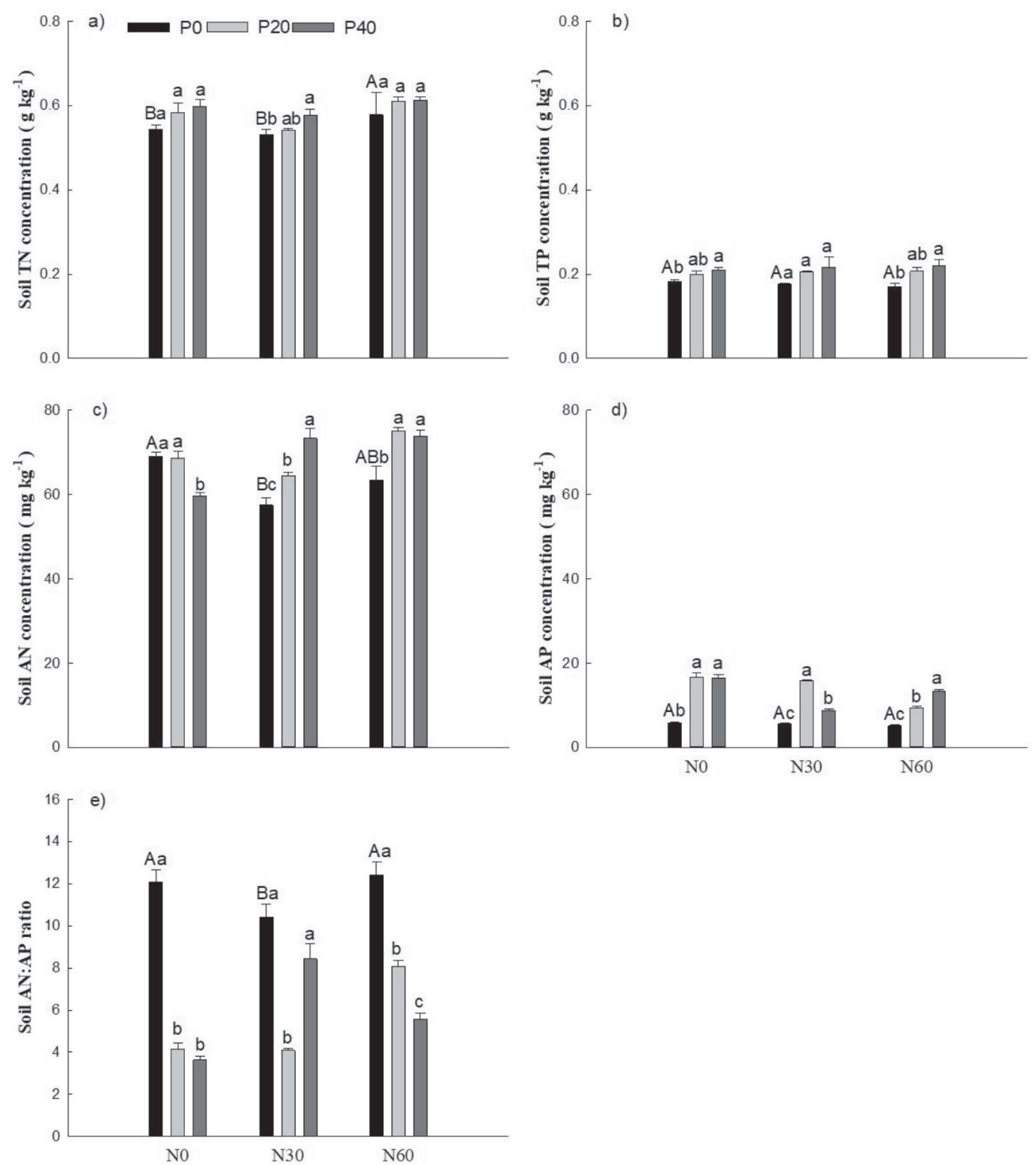

Fig. S1. Effects of $\mathrm{N}$ deposition (N0, $\left.0 \mathrm{~kg} \mathrm{~N} \mathrm{ha}^{-1} \mathrm{yr}^{-1} ; \mathrm{N} 30,30 \mathrm{~kg} \mathrm{~N} \mathrm{ha}^{-1} \mathrm{yr}^{-1} ; \mathrm{N} 60,60 \mathrm{~kg} \mathrm{~N} \mathrm{ha}^{-1} \mathrm{yr}^{-1}\right)$ and $\mathrm{P}$ addition $\left(\mathrm{P} 0,0 \mathrm{mg} \mathrm{kg}{ }^{-1} ; \mathrm{P} 20\right.$, $20 \mathrm{mg} \mathrm{kg}^{-1}$; P40, $40 \mathrm{mg} \mathrm{kg}^{-1}$ ) on soil total nitrogen (TN), total phosphorus (TP), available nitrogen (AN), available phosphorus (AP) and AN:AP ratio. Different capital letters indicate significant differences among $\mathrm{N}$ addition alone $(P<0.05)$. Different lowercase letters indicate significant differences among $\mathrm{P}$ addition at the identical $\mathrm{N}$ addition $(P<0.05)$. 


\section{References}

1. KERKHOFF A.J., FAGAN W.F., ELSER J.J., ENQUIST B.J. Phylogentic and growth form variation in the scaling of nitrogen and phosphorus in the seed plants. Am Nat. 168, 103, 2006.

2. LIU C., WANG Y., WANG N., WANG G. Advances research in plant nitrogen, phosphorus and their stoichiometry in terrestrial ecosystems: a review. Chin J Plant Ecol. 36, 1205, 2012.

3. ELSER J.J., FAGAN W.F., KERKHOF A.J., SWENSON N.G., ENQUIST B.J. Biological stoichiometry of plant production: Metabolism, scaling and ecological response to global change. New Phytol. 186, 593, 2010.

4. MATZEK V., VITOUSEK P.M. N:P stoichiometry and protein: RNA ratios in vascular plants: an evaluation of the growth-rate hypothesis. Ecol Lett. 12, 765, 2009.

5. SARDANS J., ALONSO R., JANSSENS I.A., CARNICER J., VERESEGLOU S., RILLIG M.C., FERNANDEZMARTINEZ M., SANDERS T.G.M., PENUELAS J. Foliar and soil concentrations and stoichiometry of nitrogen and phosphorous across European Pinus sylvestris forests: relationships with climate, $\mathrm{N}$ deposition and tree growth. Funct Ecol. 30, 676, 2016.

6. VITOUSEK P.M., PORDER S., HOULTON B.Z., CHADWICK O.A. Terrestrial phosphorus limitation: mechanisms, implications, and nitrogen-phosphorus interactions. Ecol Appl. 20, 5, 2010.

7. PEÑUELAS J., POULTER B., SARDANS J., CIAIS P., VELDE M., BOPP L., BOUCHER O., GODDERIS Y., HINSINGER P., LLUSIA J., NARDIN E., VICCA S., OBERSTEINER M., JANSSENS I.A. Human-induced nitrogen-phosphorus imbalances alter natural and managed ecosystems across the globe. Nat. Commun. 4, 2934, 2013.

8. LI Y., NIU S., YU G. Aggravated phosphorus limitation on biomass production under increasing nitrogen loading: a metanalysis. Global Change Biol. 22, 934, 2016.

9. PENG Y., PENG Z., ZENG X., HOUX J.H. Effects of nitrogen-phosphorus imbalance on plant biomass production: a global perspective. Plant Soil. 436, 245, 2019.

10. EDENHOFER O., SEYBOTH K. Intergovernmental Panel on Climate Change (IPCC). Enc Energ, Natural Resour, Environ Econ. 48, 2013.

11. FERRETTI M., MARCHETTO A., ARISCI S., BUSSOTTI F., CALDERISI M., CARNICELLI S., CECCHINI G., FABBIO G., BERTINI G., MATTEUCCI G., CINTI B., SALVATI L., POMPEI E. On the tracks of Nitrogen deposition effects on temperate forests at their southern European range-an observational study from Italy. Global Change Biol. 20, 3423, 2014.

12. DU E., WIM D.V., HAN W., LIU X., YAN Z., JIANG Y. Imbalanced phosphorus and nitrogen deposition in China's forests. Atmos Chem Phys. 1, 2016.

13. SARDANS J., GRAU O., CHEN H., JANSSENS I.A., CIAIS P., PIAO S. Changes in nutrient concentrations of leaves and roots in response to global change factors. Global Change Biol. 23, 3849, 2017.

14. ZHAN S., WANG Y., ZHU Z., LI W., BAI Y. Nitrogen enrichment alters plant N:P stoichiometry and intensifes phosphorus limitation in a steppe ecosystem. Environ Exp Bot. 134, 21, 2017.

15. HUANG Z., LIU B., DAVIS M., SARDANS J., PENUELAS J., BILLINGS S. Long-term nitrogen deposition linked to reduced water use efficiency in forests with low phosphorus availability. New Phytol. 210, 431, 2016.

16. VERESOGLOU S.D., PEÑUELAS J., FISCHER R., RAUTIO P., SARDANS J., Merilä P., MARA T.T., RILLIG M.C. Exploring continental-scale stand health $\mathrm{N}: \mathrm{P}$ ratio relationships for European forests. New Phytol. 202, 422, 2014.

17. TALKNER U., MEIWES K.J., POTOČIĆ N., SELETKOVIĆ I., COOLS N., VOS B.D., RAUTIO P. Phosphorus nutrition of beech (Fagus sylvatica L.) is decreasing in europe. Ann For Sci. 72, 919, 2015.

18. SONG X., GU H., WANG M., ZHOU G., LI Q. Management practices regulate the response of Moso bamboo foliar stoichiometry to nitrogen deposition. Sci Rep. 6, 24107, 2016.

19. ZHANG H., CHANG R., GUO X., LIANG X., WANG R., LIU J. Shifs in growth and competitive dominance of the invasive plant Alternanthera philoxeroides under diferent nitrogen and phosphorus supply. Environ Exp Bot. 135, 118, 2017.

20. DENG Q., HUI D., LUO Y., ELSER J., WANG Y., LOLADZE I., ZHANG Q., DENNIS S. Down-regulation of tissue $\mathrm{N}: \mathrm{P}$ ratios in terrestrial plants by elevated $\mathrm{CO}_{2}$. Ecology. 96, 3354, 2015

21. ZHANG R., ZHAO Y., LIN J., HU Y., HÄNNINEN H., WU J. Biochar application alleviates unbalanced nutrient uptake caused by $\mathrm{N}$ deposition in Torreya grandis trees and seedlings. Forest Ecol Manag. 432, 319, 2019.

22. HUANG J., YU H., LIU J., LUO C., SUN Z., MA K., KANG Y., DU Y. Phosphorus addition changes BGB and $\mathrm{C}: \mathrm{N}$ : P stoichiometry of two desert steppe plants under simulated N deposition. Sci Rep. 8, 3400, 2018.

23. YU X. Research and views on the sustainable use of Chinese fir forest land. World Forestry Res. 2, 80, 1993.

24. LIU L., XU M., WANG S., ZHANG Q., HU J. Effect of different Cunninghamia lanceolata plantation soil qualities on soil microbial community structure. Acta Ecol Sin. 33, 4692, 2013

25. TONG R., ZHOU B., JIANG L., GE X., CAO Y., YANG Z. Leaf Nitrogen and Phosphorus Stoichiometry of Chinese fir Plantations across China: A Meta-Analysis. Forests. 10, 945, 2019.

26. JIA Y., YU G., HE N., ZHAN X., FANG H., SHENG W., ZUO Y., ZHANG D., WANG Q. Spatial and decadal variations in inorganic nitrogen wet deposition in China induced by human activity. Sci Rep. 4, 3763, 2014.

27. REAY D.S., DENTENER F., SMITH P., GRACE J., FEELY R.A. Global nitrogen deposition and carbon sinks. Nature Geosci. 1, 430, 2008.

28. SONG X., ZHOU G., GU H., QI L. Management practices amplify the effects of $\mathrm{N}$ deposition on leaf litter decomposition of the Moso bamboo forest. Plant Soil, 395, 391, 2015.

29. HINSINGER P. Bioavailability of soil inorganic $P$ in the rhizosphere as affected by root-induced chemical changes: a review. Plant Soil. 237, 173, 2001.

30. LIU X., ZHOU G., ZHANG D., LIU S., CHU G., YAN J. $\mathrm{N}$ and $\mathrm{P}$ stoichiometry of Plant Soil in lower subtropical forest successional series in southern China. Chin J Plant Ecol. 34, 64, 2010.

31. LI J., XU W., XIONG G., WANG Y., ZHAO C., LU Z., LI Y., XIE Z. Leaf nitrogen and phosphorus concentration and the empirical regulations in dominant woody plants of shrublands across southern China. Chin J Plant Ecol. 41, 31, 2017. 
32. WANG Q., ZHANG J., LEI Z., LI Q., HUANG H., SONG $\mathrm{X}$. Effects of simulated nitrogen deposition and phosphorus addition on the eco-stoichiometric characteristics of Chinese fir. Chin J Ecol. 38, 62, 2019

33. SONG X., LI Q., GU H. Effect of nitrogen deposition and management practices on fine root decomposition in Moso bamboo plantations. Plant Soil. 410, 207, 2017.

34. LIU L., GUNDERSEN P., ZHANG W., ZHANG T., CHEN H., MO J. Effects of nitrogen and phosphorus additions on soil microbial biomass and community structure in two reforested tropical forests. Sci Rep. 5, 14378, 2015.

35. SONG X., JIANG H., ZHANG Z., ZHOU G., ZHANG S., PENG C. Interactive effects of elevated UV-B radiation and $\mathrm{N}$ deposition on Moso bamboo litter decomposition. Soil Biol Biochem. 69, 11, 2014.

36. WATANABE F.S., OLSEN S.R. Test of an ascorbic acid method for determining phosphorus in water and $\mathrm{NaCO}_{3}$ extracts from soil. Soil Sci Soc Am J. 29, 677, 1965.

37. LU R. Methods for soil agrochemistry analysis. China Ag Sci Tec Press. 2000.

38. MACK M.C., SCHUUR E.A.G., BRET-HARTE M.S., SHAVER G.R., CHAPIN F.S. Ecosystem carbon storage in arctic tundra reduced by long-term nutrient fertilization. Nature. 431, 440, 2004.

39. ROSENGREN B.U., MAJDI H., ASP H., WIDELL S. Enzyme activities in isolated root plasma membranes from a stand of Norway spruce in relation to nutrient status and ammonium sulphate application. New Phytol. 129, 537, 1995.

40. LI D., MO J., PENG S., FANG Y. Effects of simulated nitrogen deposition on elemental concentrations of Schima superba and Cryptocarya concinna seedlings in subtropical China. Acta Ecol Sin. 25, 2165, 2005.

41. MOLLIER A., PELLERIN S. Maize root system growth and development as influenced by phosphorous deficiency. J Exp Bot. 50, 487, 1999.

42. LI S., HU C., GONG J., DONG S., DONG Z. Effects of Low Phosphorus Stress on the Chlorophyll Fluorescence of Different Phosphorus Use Efficient Maize (Zea mays L.). Acta Ecol Sin. 30, 365, 2004.

43. DONG Q., ZHAO H., ZHANG X., ZHANG W., ZHANG $H$., ZHANG K. Differences in morphological and physiological responses of different wild soybeans under low phosphorus stress. Jiangsu Agric Sci. 45, 79, 2017.

44. TAIZ L., ZEIGER E. Plant Physiology. Q Rev Biol. 167, 161, 2006.

45. REICH P.B., WALTERS M.B., ELLSWORTH D.S. From tropics to tundra: global convergence in plant functioning. P Natl Acad Sci. 94, 13730, 1997.

46. NAKAJI T., FUKAMI M., DOKIYA Y., IZUTA T. Effects of high nitrogen load on growth, photosynthesis and nutrient status of Cryptomeria japonica and Pinus densiflora seedlings. Trees. 15, 453, 2001.

47. LIU M., WANG Y., LI Q., XIAO W., SONG X. Photosynthesis, ecological stoichiometry, and NonStructural carbohydrate response to simulated nitrogen deposition and phosphorus addition in Chinese fir forests. Forests. 10, 2, 2019.

48. HOVENDEN M.J., NEWTON P.C., WILLS K.E. Seasonal not annual rainfall determines grassland biomass response to carbon dioxide. Nature. 511, 583, 2014.

49. YANG Y., FANG J., MA W., GUO D., MOHAMMAT A. Large-scale pattern of biomass partitioning across China's grasslands. Global Ecol Biogeogr. 19, 268, 2010.
50. LUO X., MAZER S.J., GUO H., ZHANG N., WEINER J., HU S. Nitrogen: phosphorous supply ratio and allometry in five alpine plant species. Ecol Evol. 6, 8881, 2016.

51. ZHANG R., ZHANG Y., SONG L., SONG X., Hänninen H., WU J. Biochar enhances nut quality of, Torreya grandis, and soil fertility under simulated nitrogen deposition. Forest Ecol Manag. 391, 321, 2017.

52. LAN Z., BAI Y. Testing mechanisms of N-enrichment induced species loss in a semiarid Inner Mongolia grassland: critical thresholds and implications for longterm ecosystem responses. Philos T Roy Soc B. 367, 3125, 2012.

53. JONARD M., FÜRST A., VERSTRAETEN A., THIMONIER A., TIMMERMANN V., POTOČIĆ N., WALDNER P., BENHAM S., HANSEN K., MERILÄ P., PONETTE Q., CRUZ A.C., ROSKAMS P., NICOLAS M., CROISE L., INGERSLEV M., MATTEUCCI G., DECINTI B., BASCIETTO M., RAUTIO P. Tree mineral nutrition is deteriorating in Europe. Global Change Biol. 21, 418, 2015.

54. TESSIER J.T., RAYNAL D.J. Use of nitrogen to phosphorus ratios in plant tissue as an indicator of nutrient limitation and nitrogen saturation. J Appl Ecol. 40, 523, 2003.

55. MEHTA P., RANA B.S., VERMA S.K. Effect of nitrogen and phosphorus fertilizers on seedling growth and biomass of teak (tectona grandis, linn. f.) on sodic soil. Indian Forester. 138, 4839, 2012.

56. ZHANG J., LI B., WANG B., GUO C., LI Y., XIAO K. Studies on the Characteristics of Photosynthesis and Dry Matter Production in Wheat Varieties with Different $\mathrm{P}$ Efficiency. Sci Agric Sin. 39, 2200, 2006.

57. WANG S., Yang J., HAN X., LIU X., ZHAN X., LIU $X$. Effects of Different Fertilization Treatments on Photosynthetic Characteristics of Spring Maize. Soil Fer Sci China. 6, 23, 2008.

58. CROUS K.Y., O'SULLIVAN O.S., ZARAGOZACASTELLS J., BLOOMFIELD K.J., NEGRINI A.C.A., MEIR P., TURNBULL M.H., GRIFFIN K.L., ATKIN O.K. Nitrogen and phosphorus availabilities interact to modulate leaf trait scaling relationships across six plant functional types in a controlled-environment study. New Phytol. 215, 992, 2017.

59. LIU Y., ZHANG J., CHEN Y., CHEN L., LIU Q. Effect of nitrogen and phosphorus fertilization on biomass allocation and $\mathrm{C}: \mathrm{N}$ : $\mathrm{P}$ stoichiometric characteristics of Eucalyptus grandis seedlings. Chin J Plant Ecol. 37, 933, 2013.

60. DRENOVSKY R.E., RICHARDS J.H. Critical N:P values: predicting nutrient deficiencies in desert shrublands. Plant Soil. 259, 59, 2004.

61. REN S., YU G., TAO B., WANG S. Chemometric characteristics of nitrogen and phosphorus in leaf of 654 plants in the North-South transect of eastern China. Environ Sci. 28, 2665, 2007.

62. WU C., FAN Z., WANG Z. Effect of phosphorus stress on chlorophyll biosynthesis, photosynthesis and biomass partitioning pattern of Fraxinus mandchurica seedlings. Chin J Appl Ecol. 15, 935, 2004.

63. GUO S., LI W., ZHANG R., WANG G. Effects of nitrogen and phosphorus addition on stoichiometry and photosynthetic characteristics of shrubby cinquefoil (Potentilla fruticosa) leaves. Guihaia. 34, 629, 2014. 
